\section{Response of Hazelnut Accessions to Greenhouse Inoculation with Anisogramma anomala}

Vidyasagar R. Sathuvalli, Shawn A. Mehlenbacher', and David C. Smith Oregon State University, Department of Horticulture, 4017 Agricultural and Life Sciences Building, Corvallis, OR 97331

Additional index words. Corylus avellana, eastern filbert blight, disease resistance

\begin{abstract}
Eastern filbert blight (EFB), caused by the pyrenomycete Anisogramma anomala (Peck) E. Müller, is a devastating disease of European hazelnut (Corylus avellana L.) in the Pacific Northwest. Host genetic resistance from 'Gasaway' has been used extensively for breeding hazelnuts at Oregon State University. Concern over the durability of this single-gene resistance prompted a search for new sources of resistance. In this study, 86 accessions from 11 countries were evaluated for their response to greenhouse inoculation with the pathogen. Nine accessions showed complete resistance, including one from Chile ('Amarillo Tardio'), two from Serbia ('Crvenje' and 'Uebov'), one from southern Russia (OSU 495.072) and five from Moscow, Russia. These new sources of EFB resistance have geographically diverse origins and will broaden the genetic base of EFB-resistant hazelnut germplasm. The previously reported resistance of 'Grand Traverse' from Michigan and the susceptibility of 'Closca Molla' from Spain were confirmed.
\end{abstract}

European hazelnut (Corylus avellana L.) is an important world crop. In the United States, hazelnuts are produced primarily in the Willamette Valley of Oregon and represent $4 \%$ to $5 \%$ of the world total (FAOStat, 2009). However, the Oregon hazelnut industry is threatened by the disease eastern filbert blight (EFB) caused by the pyrenomycete Anisogramma anomala (Peck) E. Müller. The fungus, an obligate biotroph with a 2year life cycle (Pinkerton et al., 1995), causes severe stem cankers on commercially important European hazelnuts. Ascospores are released from perithecia during periods of branch wetness in winter and spring and dispersed by splashing rain and air currents. The spores germinate and produce hyphae that directly penetrate young growing shoots in the spring. The hyphae permeate and destroy the cambial layer, and cankers bearing stromata become visible 16 to 18 months after initial infection (Johnson et al., 1994; Pinkerton et al., 1998; Stone et al., 1992). Control measures include scouting and pruning infected branches below the cankers plus fungicide treatments at 2-week intervals starting at budbreak (Pscheidt, 2006).

Host genetic resistance is a desirable way to avoid the expense and time involved in scouting, pruning, and spraying to control this disease (Mehlenbacher, 1995). The resistance from 'Gasaway', an obsolete pollinizer (Mehlenbacher et al., 1991), has been extensively used in the hazelnut breeding program at Oregon State University (OSU).

Received for publication 4 Mar. 2010. Accepted for publication 27 Mar. 2010.

${ }^{1}$ To whom reprint requests should be addressed; e-mail mehlenbs@hort.oregonstate.edu.
Concern over the durability of this single resistance gene prompted this search for new sources of resistance to EFB. Inoculations by Molnar (2006) with different isolates of $A$. anomala showed that an isolate from Michigan produced a few cankers on 'Gasaway' and suggested genetic diversity among isolates of the pathogen. A series of studies (Chen et al., 2007; Coyne et al., 1998; Lunde et al., 2000) has identified several new sources of resistance. Molecular markers linked to resistance have been identified for some of these (Chen et al., 2005; Sathuvalli, 2007). In this study, the response of 86 hazelnut accessions recently introduced from several countries was evaluated after greenhouse inoculations with the EFB pathogen.

\section{Materials and Methods}

Plant materials. The tested accessions were obtained from 11 countries (Tables 1 and 2) and included 35 from Russia, 21 from Azerbaijan, seven from Georgia, and six each from the Ukraine and Serbia. One was a selection from imported seeds, and 85 were received as scions. After their introduction, scions were grafted to rooted layers of $C$. avellana, and the trees were held in postentry quarantine in the greenhouse for two growing seasons. The trees were then planted in the field at OSU's Smith Horticultural Research Farm in Corvallis, OR. For disease inoculations, scions were collected in the field or the lathhouse in December to January over a 5year period (2004 to 2008), stored at $-1{ }^{\circ} \mathrm{C}$, and three scions per accession were grafted to C. avellana rooted layers in May to June. The grafted plants were potted in 5-L pots containing a mixture of equal volumes of peat, pumice, and fine bark dust to which $9 \mathrm{~g}$ of
Sierra 3-4 month release fertilizer (18N-6P12K) (Peters Professional, Allentown, PA) was added. The grafted trees were grown in a greenhouse under optimal conditions $\left(24{ }^{\circ} \mathrm{C}\right.$ day $/ 18{ }^{\circ} \mathrm{C}$ night) for a few weeks until they were ready for inoculation.

Disease inoculation. Cankered shoots with mature stromata were collected in December annually from diseased trees from various orchards in the Willamette Valley over 5 years (2003 to 2007). They were stored at $-20{ }^{\circ} \mathrm{C}$ until used. Inoculation chambers were set up in the greenhouse using polyvinyl chloride tubing $(1.27 \mathrm{~cm}$ diameter) placed on top of benches $(2.44 \mathrm{~m} \times 0.88 \mathrm{~m})$ and covered with white 4-mil polythene sheeting. In the first 3 years (2003 to 2005), the chamber's roof was closed and high humidity was maintained using humidifiers as described by Chen et al. (2007). In the next 2 years (2006 to 2007), the roof was open and humidifiers were replaced with mist nozzles. Three misters $\left(7.57 \mathrm{~L} \cdot \mathrm{h}^{-1}\right)$ per bench were placed $0.3 \mathrm{~m}$ apart, $0.9 \mathrm{~m}$ above the bench top, and set to operate for $10 \mathrm{~s}$ every $30 \mathrm{~min}$ during the day time ( $0800 \mathrm{HR}$ to $1900 \mathrm{HR}$ ) and $10 \mathrm{~s}$ every hour during the night (1900 HR to $0800 \mathrm{HR}$ ) using an automated misting unit (Model No. DE 8 PR2; Davis Engineering, Canoga Park, CA). Grafted plants were inoculated when the shoots had four to five nodes (Coyne et al., 1998) and actively growing shoot tips.

Perithecia from the diseased twigs were dissected, ground with a mortar and pestle to release ascospores, and diluted in water to a concentration of $1 \times 10^{6}$ spores $/ \mathrm{mL}$. Two inoculations at a 3-d interval were carried out either in the evening (2000 $\mathrm{HR}$ to $2200 \mathrm{HR}$ ) or early morning ( $0500 \mathrm{HR}-$ to $0700 \mathrm{HR})$ to reduce the risk of escapes. The spore suspension was sprayed on shoot tips until they were visibly damp but not dripping wet. The inoculated trees were moved out of the inoculation chamber $3 \mathrm{~d}$ after the second inoculation and grown in the greenhouse at optimal temperatures $\left(24{ }^{\circ} \mathrm{C}\right.$ day $/ 18^{\circ} \mathrm{C}$ night $)$. In October, the trees were planted in a nursery row at the Smith Farm. 'Gasaway' was included as the resistant control, and 'Ennis', 'Daviana', and 'Tonda di Giffoni' were the susceptible controls. 'Ennis' and 'Daviana' are highly susceptible to EFB, whereas 'Tonda di Giffoni' has a high level of quantitative resistance.

Disease susceptibility evaluation. The inoculated plants were visually evaluated for the presence of cankers 16 to 20 months after inoculation. A genotype was scored as susceptible if cankers with stromata were observed on one or more of the three trees and scored as resistant if all three trees remained free of infection. Tests were repeated a second year for nine of the accessions scored as resistant, but 'Amarillo Tardio' was tested only once.

Description of resistant accessions. The newly identified resistant accessions were described using standard descriptors used in the OSU hazelnut breeding program (Table 3 ). Most of these descriptions are based on a single tree and 1 to 6 years of observation. 
Table 1. Response of 52 hazelnut accessions to greenhouse inoculation with Anisogramma anomala.

\begin{tabular}{|c|c|c|c|}
\hline Accession & Origin & Yr of inoculation & Disease response \\
\hline Amarillo Tardio & Chillán, Chile & 2008 & Resistant \\
\hline Crvenje & Čačak, Serbia & 2003,2006 & " \\
\hline Grand Traverse & Lansing, MI & 2005,2006 & $"$ \\
\hline OSU 495.072 & southern Russia & 2005,2007 & $"$ \\
\hline Uebov & Čačak, Serbia & 2003,2006 & " \\
\hline Anakliuri & Vani, GA & 2004,2007 & Susceptible \\
\hline Arzu & Zaqatala, Azerbaijan & 2004,2007 & " \\
\hline Ashrafi & Zaqatala, Azerbaijan & 2004,2007 & $"$ \\
\hline Aslan Baba & Zaqatala, Azerbaijan & 2004,2007 & $"$ \\
\hline Ata Baba & Zaqatala, Azerbaijan & $2004,2006,2007$ & $"$ \\
\hline Ata Ula & Zaqatala, Azerbaijan & 2004,2007 & $"$ \\
\hline Azeri & Zaqatala, Azerbaijan & 2004 & " \\
\hline Barli & Zaqatala, Azerbaijan & 2004,2007 & " \\
\hline Bomba & Zaqatala, Azerbaijan & 2004 & $"$ \\
\hline Borovskoi & Kharkiv, Ukraine & 2003 & " \\
\hline Catalan & Krakow, Poland & 2003 & $"$ \\
\hline Chikvistava & Vani, GA & 2004 & $"$ \\
\hline Closca Molla & Reus, Spain & 2005,2006 & $"$ \\
\hline Dalian 83-81 & Dalian, China & 2006 & $"$ \\
\hline Dalian 84-161 & Dalian, China & 2006 & $"$ \\
\hline Dalian 84-349 & Dalian, China & 2006 & $"$ \\
\hline Dalian $84-75$ & Dalian, China & 2006 & $"$ \\
\hline Dedoplis Titi & Vani, GA & 2004 & $"$ \\
\hline Dnepr1 & Kharkiv, Ukraine & 2003 & " \\
\hline Dučalovići 30/96 & Čačak, Serbia & 2003 & $"$ \\
\hline Elbari & Zaqatala, Azerbaijan & 2004,2006 & " \\
\hline Firavan & Zaqatala, Azerbaijan & 2004,2006 & $"$ \\
\hline Galib & Zaqatala, Azerbaijan & 2004,2007 & $"$ \\
\hline Ganja & Zaqatala, Azerbaijan & $2004,2006,2007$ & $"$ \\
\hline Gauna & Viedma, Argentina & 2008 & $"$ \\
\hline Gizil Findiq & Zaqatala, Azerbaijan & 2004 & $"$ \\
\hline Gobekli & Zaqatala, Azerbaijan & 2004 & " \\
\hline Gulshishvela & Vani, GA & 2004,2007 & $"$ \\
\hline Khachapura & Vani, GA & 2004, 2007 & " \\
\hline Lozovskoi Sharovidnii & Kharkiv, Ukraine & $2003,2005,2006$ & $"$ \\
\hline Mar del Plata & Viedma, Argentina & 2008 & $"$ \\
\hline Nasimi & Zaqatala, Azerbaijan & 2004,2007 & " \\
\hline Nemsa & Vani, GA & 2004 & " \\
\hline Pirosok & Kharkiv, Ukraine & 2003 & $"$ \\
\hline Qabala & Zaqatala, Azerbaijan & 2004,2006 & $"$ \\
\hline Reka I & Čačak, Serbia & 2003 & $"$ \\
\hline Reka II & Čačak, Serbia & 2003 & " \\
\hline Sachakhli & Zaqatala, Azerbaijan & 2004, 2007 & " \\
\hline Shveliskura & Vani, GA & 2004 & $"$ \\
\hline Suvodol & Kharkiv, Ukraine & 2003 & " \\
\hline Tala & Zaqatala, Azerbaijan & 2004,2007 & $"$ \\
\hline Topkhara & Zaqatala, Azerbaijan & 2004,2007 & $"$ \\
\hline Trbusani & Čačak, Serbia & 2003 & " \\
\hline Uzum Sakar & Zaqatala, Azerbaijan & 2004,2007 & $"$ \\
\hline Veleten & Kharkiv, Ukraine & 2003 & $"$ \\
\hline Verde & Chillán, Chile & 2008 & $"$ \\
\hline Yagli Findiq & Zaqatala, Azerbaijan & 2004,2006 & $"$ \\
\hline
\end{tabular}

Data from a replicated yield trial planted in 1998 are presented for comparison.

\section{Results and Discussion}

Over the 5-year period, the disease response of 86 hazelnut accessions was assessed. Of these, 76 were susceptible and 10 were resistant (Tables 1 and 2). The resistant control 'Gasaway' remained free of EFB in all tests. The highly susceptible controls 'Ennis' and 'Daviana' became infected in all years and the moderately susceptible control 'Tonda di Giffoni' produced few cankers with stromata. Actively growing shoot tips are essential for successful inoculations (Johnson et al., 1994; Stone et al., 1992). We reduced the number of inoculations from three as used previously
Table 2. Response of 34 hazelnut accessions from the Russian Research Institute of Forestry and Mechanization $^{\mathrm{z}}$ to greenhouse inoculation with Anisogramma anomala.

\begin{tabular}{|c|c|c|}
\hline Selection & Yr of inoculation & Disease response \\
\hline N01 & 2005,2007 & Resistant \\
\hline N02 & 2005,2007 & " \\
\hline N26 & 2005,2007 & " \\
\hline $\mathrm{N} 27$ & 2005, 2007 & " \\
\hline N37 & 2005, 2007 & $"$ \\
\hline N01-08 & 2005,2007 & Susceptible \\
\hline N01-13 & 2005 & " \\
\hline N05 & 2005 & $"$ \\
\hline N06 & 2005 & $"$ \\
\hline N07 & 2005,2007 & $"$ \\
\hline N08 & 2005 & $"$ \\
\hline N09 & 2005,2007 & $"$ \\
\hline N10 & 2005,2007 & " \\
\hline N11 & 2005 & " \\
\hline N12 & 2005 & $"$ \\
\hline N13 & 2005 & $"$ \\
\hline N14 & 2005, 2007 & $"$ \\
\hline N15 & 2005 & $"$ \\
\hline $\mathrm{N} 21$ & 2005,2007 & " \\
\hline N22 & 2005 & " \\
\hline N24 & 2005 & $"$ \\
\hline $\mathrm{N} 28$ & 2005 & $"$ \\
\hline N30 & 2005 & $"$ \\
\hline N31 & 2005 & " \\
\hline N33 & 2005,2007 & " \\
\hline N34 & 2005,2007 & " \\
\hline N35 & 2005,2007 & $"$ \\
\hline N36 & 2005 & $"$ \\
\hline N38 & 2005,2007 & $"$ \\
\hline N39 & 2005 & $"$ \\
\hline N40 & 2005 & $"$ \\
\hline N43 & 2005 & $"$ \\
\hline N44 & 2005, 2007 & $"$ \\
\hline N45 & 2005 & $"$ \\
\hline
\end{tabular}

${ }^{\mathrm{z} 15}$ Institutskaya Street, Pushkino, Moscow Province 141202 Russian Federation.

exposed under a structure topped with diseased wood, 'Lozovkoi Sharovidnii' from the Ukraine developed a few small cankers with very few stromata (data not shown) indicating possible resistance. However, 'Lozovskoi Sharovidnii' was susceptible in our greenhouse inoculations. Of seven accessions from Čačak, Serbia, two ('Crvenje' and 'Uebov') showed complete resistance to EFB. Four selections from Dalian, China, were susceptible to EFB; all are hybrids between $C$. heterophylla Fisch. and C. avellana.

Lunde et al. (2000) reported that 'Grand Traverse' from Michigan and 'Closca Molla' from Spain were resistant, but Chen et al. (2007) later observed cankers on 'Closca Molla' exposed under a structure topped with diseased wood. Our greenhouse inoculations of 'Closca Molla' confirmed its susceptibility. Molnar (2006) inoculated 'Closca Molla' with several isolates of $A$. anomala and also reported it to be susceptible. Our studies, and those of Molnar (2006), confirmed the resistance of 'Grand Traverse'. 'Grand Traverse' has nearly round nuts with a high kernel percentage $(51 \%)$ and kernels have little fiber. It was introduced for the in-shell trade (The Brooks and Olmo Register of Fruit and Nut Varieties, 1997). The tree is vigorous, productive, winter-hardy, and resistant to bud mites but not precocious. 
Table 3. Description of nine hazelnut accessions with complete resistance to eastern filbert blight, and four cultivars from a trial planted in Corvallis, OR, in 1998 .

\begin{tabular}{|c|c|c|c|c|c|c|c|c|c|c|c|c|c|c|c|c|}
\hline \multirow[b]{2}{*}{ Cultivar } & \multirow{2}{*}{$\begin{array}{c}\text { No. } \\
\text { of } \\
\text { years }\end{array}$} & \multirow[b]{2}{*}{$\begin{array}{c}10 \text {-nut } \\
\mathrm{wt}^{\mathrm{x}}\end{array}$} & \multirow[b]{2}{*}{$\begin{array}{c}\text { 10-kernel } \\
\mathrm{wt}^{\mathrm{x}}\end{array}$} & \multirow[b]{2}{*}{$\begin{array}{c}\text { Kernel } \\
\text { percentagew }\end{array}$} & \multirow[b]{2}{*}{ Fiberv } & \multirow[b]{2}{*}{ Blanching $^{\mathrm{u}}$} & \multicolumn{8}{|c|}{ Frequency $(\%)^{z}$} & \multirow{2}{*}{\multicolumn{2}{|c|}{$\begin{array}{r}\text { Bud } \\
\text { mite } \\
\text { Maturity }^{\text {t }} \text { rating }\end{array}$}} \\
\hline & & & & & & & Good & I Blanks & $\begin{array}{c}\text { Brown } \\
\text { stain }\end{array}$ & $\begin{array}{l}\text { Moldy } \\
\text { kernels }\end{array}$ & $\begin{array}{c}\text { Shriveled } \\
\text { kernels }\end{array}$ & $\begin{array}{l}\text { Poorly } \\
\text { filled }\end{array}$ & Doubles & $\begin{array}{c}\text { Black } \\
\text { tips }\end{array}$ & & \\
\hline \multicolumn{17}{|c|}{ Accessions resistant to eastern filbert blight } \\
\hline Amarillo Tardio & 1 & 18.3 & 7.2 & 39.47 & 2 & 4.5 & 41.0 & 12.0 & 10.0 & 4.0 & 5.0 & 32.0 & 0.0 & 0.0 & +0 & 2.17 \\
\hline OSU 495.072 & 6 & 19.8 & 8.1 & 40.96 & 4 & 2.8 & 94.0 & 4.0 & 0.0 & 0.0 & 0.5 & 1.5 & 0.0 & 0.0 & -3 & 2.25 \\
\hline Uebov & 3 & 44.3 & 20.6 & 31.12 & 2.2 & 3.5 & 73.0 & 1.7 & 0.0 & 5.7 & 0.7 & 11.3 & 1.3 & 7.0 & +4 & 1.00 \\
\hline N01 & 1 & 17.9 & 7.3 & 40.83 & 3 & 3 & 92.0 & 6.0 & 0.0 & 0.0 & 1.0 & 1.0 & 0.0 & 0.0 & -10 & 2.90 \\
\hline N27 & 1 & 24.6 & 11.0 & 44.72 & 2 & 6 & 34.0 & 62.0 & 0.0 & 0.0 & 0.0 & 4.0 & 0.0 & 0.0 & -10 & 2.00 \\
\hline N37 & 1 & 16.1 & 8.1 & 50.16 & 3 & 4 & 68.0 & 1.0 & 0.0 & 0.0 & 10.0 & 21.0 & 0.0 & 0.0 & -10 & 2.00 \\
\hline \multicolumn{17}{|c|}{ Cultivars in trial planted in 1998} \\
\hline Barcelona & 4 & 36.0 & 15.9 & 44.23 & 2.5 & 4.03 & 58.0 & 8.9 & 0.4 & 1.8 & 3.6 & 25.0 & 2.7 & 0.1 & +0 & 1.04 \\
\hline Clark & 4 & 24.3 & 12.4 & 51.23 & 2.31 & 2.84 & 78.6 & 2.4 & 2.4 & 3.5 & 0.7 & 11.6 & 0.4 & 1.1 & -8 & 3.11 \\
\hline Lewis & 4 & 26.1 & 12.4 & 47.44 & 1.09 & 3.91 & 70.6 & 2.6 & 0.3 & 4.6 & 1.2 & 20.9 & 0.6 & 0.4 & -5 & 2.25 \\
\hline
\end{tabular}

${ }^{\mathrm{z}}$ Frequency (\%) of good nuts and seven types of defects.

${ }^{y}$ Number of years of observation.

${ }^{\mathrm{x}}$ Ten-nut and 10-kernel weight in grams.

"Ratio of kernel weight to nut weight.

vFiber on pellicle rated from 1 (none) to 4 (much).

"Blanching rated from 1 (complete pellicle removal) to 7 (no pellicle removal).

'Maturity is days earlier (-) or later (+) than 'Barcelona'.

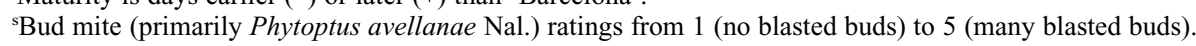

\begin{abstract}
'Amarillo Tardio' is a late-shedding pollenizer received from the Institituto Nacional de Investigaciones Agropecuarias-Quilamapu Research Station in Chillán, Chile. It is believed to be a seedling from nuts imported from Europe. Its nuts are small and round with a slight point, borne in clusters of three, and mature with 'Barcelona'. The husks are slightly shorter than the nuts, and most fall free at maturity. Of the nuts harvested in 2007, 32\% were poorly filled. 'Amarillo Tardio' pollen expresses incompatibility allele $\mathrm{S}_{2}$; the second S-allele has not been identified. The disease response
\end{abstract} of 'Amarillo Tardio' was tested only once.

'Crvenje' is a local selection received from the Agricultural Research Institute's Fruit and Grape Research Center in Čačak, Serbia. The nuts are small and long-oval, and the husks are slightly longer than the nuts. Most are borne as single nuts. The nuts fall free of the husk at maturity, $\approx 1$ week later than Barcelona. Nut yields are low, but bud mite resistance is very good. The brittle kernels are covered with fiber, blanch poorly, and often break when the nuts are cracked. It has incompatibility alleles $\mathrm{S}_{6}$ and $\mathrm{S}_{23}$.

OSU 495.072 was selected from seedlings grown from seed sent by the All-Union Institute of Plant Industry (VIR) headquarters in St. Petersburg, Russia. The collection site is unknown, but we assume that the seeds were collected at a VIR station near Krasnodar or elsewhere in the North Caucasus. A total of 91 seedlings was planted. They were vigorous with upright growth, a striking lack of precocity, and late-maturing nuts that fell free of short, open husks. In contrast, Russian cultivars from Sochi on the Black Sea coast are similar to those grown in Turkey in that they have small trees that are spreading and low in vigor, and the nuts are enclosed in long, clasping husks. The nuts of OSU 495.072 are small and round with a slight point and borne in husks $\approx 50 \%$ longer than the nuts. The nuts are in clusters of three and fall free of the husk slightly earlier than 'Barcelona'. The kernels are covered with fiber, but pellicle removal scores are good. Resistance to bud mite (primarily Phytoptus avellanae Nal.) is good and similar to 'Lewis'. It has incompatibility alleles $\mathrm{S}_{6}$ and $\mathrm{S}_{30}$, both of which are rare.

'Uebov' is a local selection received from the ARI Fruit and Grape Research Center in Čačak, Serbia. The nuts are large, attractive, and round and are borne in clusters of one or two. The husk is slightly longer than the nut and slit on the side. Nuts are well-filled for their size, but shells are thick and show a high incidence of split sutures, which results in many kernels having black tips. The nuts mature slightly later than 'Barcelona'. Nut yields are low, but the kernels are attractive and blanch well. Bud mite resistance is very good. It has incompatibility alleles $\mathrm{S}_{12}$ and $\mathrm{S}_{16}$.

Of the 34 selections imported from the Russian Research Institute of Forestry and Mechanization, five (N01, N02, N26, N27, and N37) remained free of EFB in two tests, whereas 29 others were susceptible. N01, N26, and N37 have small nuts; N27 has medium-sized nuts; and N02 has large nuts. The large nuts of N02 are well-filled for their size. All produce long nuts, and kernel percentage ranges from $41 \%$ to $50 \%$. Husk length is roughly equal to nut length. Nut maturity is more than 1 week earlier than 'Barcelona' for N01, N26, N27, and N37. The incompatibility alleles of these five selections have not yet been identified.
The geographic origins of the nine newly identified resistant accessions (six from Russia, two from Serbia, and one from Chile) suggest diversity in their resistance genes. These nine accessions should be useful in breeding hazelnuts for areas where EFB is present.

\section{Literature Cited}

Chen, H., S.A. Mehlenbacher, and D.C. Smith. 2005. AFLP markers linked to eastern filbert blight resistance from OSU 408.040 hazelnut. J. Amer. Soc. Hort. Sci. 130:412-417.

Chen, H., S.A. Mehlenbacher, and D.C. Smith. 2007. Hazelnut accessions provide new sources of resistance to eastern filbert blight. HortScience 42:466-469.

Coyne, C.J., S.A. Mehlenbacher, and D.C. Smith. 1998. Sources of resistance to eastern filbert blight in hazelnut. J. Amer. Soc. Hort. Sci. 123: 253-257.

FAOStat 2009. 24 Dec. 2009. <http://faostat.fao. org/site/567/default.aspx\#ancor $>$.

Johnson, K.B., J.N. Pinkerton, S.M. Gaudreault, and J.K. Stone. 1994. Infection of European hazelnut by Anisogramma anomala: Site of infection and effect of host development stage. Phytopathology 84:1465-1470.

Lunde, C.F., S.A. Mehlenbacher, and D.C. Smith. 2000. Survey of hazelnut cultivars for response to eastern filbert blight inoculation. HortScience 35:729-731.

Mehlenbacher, S.A. 1995. Classical and molecular approaches to breeding fruit and nut crops for disease resistance. HortScience 30:466-477.

Mehlenbacher, S.A., M.M. Thompson, and H.R. Cameron. 1991. Occurrence and inheritance of immunity to eastern filbert blight in 'Gasaway' hazelnut. HortScience 26:410-411.

Molnar, T.J. 2006. Genetic resistance to eastern filbert blight in hazelnut (Corylus). Ph.D. Diss, Department of Plant Biology, Rutgers, the State University of New Jersey, New Brunswick, NJ. Pinkerton, J.N., K.B. Johnson, J.K. Stone, and K.L. Ivors. 1998. Factors affecting the release of 
ascospores of Anisogramma anomala. Phytopathology 88:122-128.

Pinkerton, J.N., J.K. Stone, S.J. Nelson, and K.B. Johnson. 1995. Infection of European hazelnut by Anisogramma anomala: Ascospore adhesion, mode of penetration of immature shoots, and host response. Phytopathology $88: 1260-1268$.
Pscheidt, J.W. 2006. Potential EFB control programs. Proc. of the Nut Growers Society of Oregon, Washington and British Columbia 91:72-78.

Sathuvalli, V.R. 2007. DNA markers linked to novel sources of resistance to eastern filbert blight in European hazelnut (Corylus avellana L). M.S. Thesis, Department of Horticulture, Oregon State University, Corvallis, OR.
Stone, J.K., K.B. Johnson, J.N. Pinkerton, and J.W Pscheidt. 1992. Natural infection period and susceptibility of vegetative seedlings of European hazelnut to Anisogramma anomala. Plan Dis. 76:348-352.

The Brooks and Olmo Register of Fruit and Nut Varieties. 1997. 3rd Ed. ASHS Press, Alexandria, VA. pp. 307 